\title{
Blasts 60 Percent or More of Peripheral Blood White Cells
}

National Cancer Institute

\section{Source}

National Cancer Institute. Blasts 60 Percent or More of Peripheral Blood White Cells. NCI

Thesaurus. Code C163007.

A semi-quantitative microscopic finding indicating that 60 percent or more of the nucleated cells in a peripheral leukocyte sample are immature mononuclear cells. 